States of Emergence, States of Knowledge

A Comparative Sociology of International Relations in China and India

Kristensen, Peter Marcus

Published in:

European Journal of International Relations

Publication date:

2019

Document version

Peer reviewed version

Citation for published version (APA):

Kristensen, P. M. (2019). States of Emergence, States of Knowledge: A Comparative Sociology of International Relations in China and India. European Journal of International Relations, 25(3), 772-799. 
Preprint of paper accepted for publication in European Journal of International Relations

\title{
States of Emergence, States of Knowledge: A Comparative Sociology of International Relations in China and India
}

\author{
Peter Marcus Kristensen \\ University of Copenhagen
}

\begin{abstract}
This paper examines the relationship between the geopolitical rise of new powers in international relations and knowledge production in International Relations. It draws on the science studies literature on the "co-production" of science and politics to conceptualise and analyse this relationship between the 'state of emergence' and 'state of knowledge'. I argue that the 'state of emergence' should not only be conceptualised as a real-world condition external to science that imposes itself on an otherwise pure internal 'state of knowledge', but also as a scholarly sensibility, ethos and motivation that operates 'within' it. The paper illustrates the argument ethnomethodologically by interviewing IR scholars in China and India on how they themselves make sense of the emerging condition and justify their own positions and actions within it. Based on the interviews, I identify four co-productive registers connecting the state of emergence to the state of knowledge (the constitutive, civic, infrastructural, and psychological) but also find that scholars in China and India differ in their enactment of these registers.
\end{abstract}

Keywords: Rising Powers, IR theory, Co-production, The State of Emergence, China, India

\section{Introduction}

Decades of sociological inquiry into International Relations (IR) have characterised the discipline as "not so international" but "hegemonic" and dominated by the U.S. and "the West" (Wæver, 1998; Smith, 2000; Kristensen, 2015; Turton, 2015; Wemheuer-Vogelaar et al., 2016; Alejandro, 2018). The field is marked by asymmetric ignorance; a hegemonic but parochial Americo-Western core remains the primary exporter of ideas, particularly theories, while little travels from periphery to core (Tickner and Wæver, 2009; Tickner, 2013; Maliniak et al., 2018). Recent years have therefore witnessed intensified efforts to open spaces for "peripheral", "Southern", and "non-Western" scholarship in order to "decenter", "provincialise", and make IR more "global" (Nayak and Selbin, 2010; Shilliam, 2010; Tickner and Blaney, 2012; Acharya, 2014, 2016; Deciancio, 2016; Turton and Freire, 2016; Aydinli and Biltekin, 2018). ${ }^{1}$

At stake in debates on Western-centrism is not simply parochialism, ethnocentrism, and representation within the discipline, but the broader relationship between knowledge and power: how American-Western dominance in IR is entangled with, and constitutive of, American-Western dominance in world politics (Smith, 2000, 2002). Numerous studies have exposed early IR's intertwinements with imperialism (Inayatullah and Blaney, 2004; Long and Schmidt, 2005; Vitalis,

\footnotetext{
${ }^{1}$ Although there is little evidence that IR is more American/Western-centric than other social sciences (Kristensen 2015), this development is long-overdue and welcome.
} 
2015) and how the "colonial household" of IR was erected on this Western- and Eurocentric historical foundation, by and for 'the West' to address its political concerns (Agathangelou and Ling, 2004; Acharya and Buzan, 2010; Hobson, 2012). During its alleged interwar 'birth', E.H. Carr (1939: 101) argued that international theories were not disinterested but "the product of dominant nations or groups of nations [and] have been designed to perpetuate their supremacy" and Stanley Hoffmann's (1977) later characterised postwar IR as an "American Social Science" born to assist America's rise to power. Recent interventions argue that Western IR serves as "handmaiden to Western power" by reflecting its interests, identities, perspectives, and policy agendas (Smith, 2004: 507-513, 2002), that its ideas are "weapons of U.S. foreign policy" (Oren, 2018) and continue their "role in sustaining Western supremacy" (van der Pijl, 2014: x).

If IR "reflects U.S. political, economic and cultural hegemony" (Smith, 2002: 69) and "rode on the back of Western power" (Acharya and Buzan, 2010: 18), this raises a crucial but largely unexamined question: what happens if the political, economic, cultural, and military balance of power shifts away from 'the West'? Will a post-Western world bring about a post-Western discipline, and, specifically on IR theory, will rising powers become theorising powers? There are indications in the literature on the "American social science" and IR 'beyond the West', reviewed below, that rising powers tend to become production sites for IR theories, but these studies more often assume than demonstrate the relationship between rising power and theorising. Meanwhile, the more theoretically and empirically attuned historiography and sociology of IR literature is predicated on a skeptical attitude towards such 'externalist' and 'power political' explanations of developments in IR theory and warns against drawing direct, especially causal, links between 'external' developments in world politics and theorising 'inside' IR.

The ambition of this paper is to explore, theoretically and empirically, the relationship between the socio-political condition of 'risingness' and attempts to theorise in IR. What I henceforth call the state of emergence and state of knowledge. In the first, theoretical, section, I argue we need to reject the bifurcation between IR/i.r., inside/outside, internalism/externalism-in this case theorising/risingness - that guide the sociological and historiographical literature. Rather than looking for causal links between the 'external' political condition of risingness and the internal dynamics of science, I argue the state of emergence manifests itself 'inside' science as a sensibility scholars use to make sense of their own situatedness and justify their practices. Drawing on the science studies literature on the "co-production" of science and politics, I argue the state of emergence should be analysed in co-productive terms with the state of knowledge. Moreover, we need to examine comparatively and ethnomethodologically how scholars in different 'rising powers' enact the power/knowledge relation rather than assume or dismiss that a relationship between political events and theorisations exists. Rising powers do not produce knowledge, scholars do. Comparatively, this also implies that the state of emergence is no uniform condition, neither within nor between different rising powers. Scholars in rising powers embed and are embedded in the 'state of emergence' in different ways - namely in a constitutive, civic, infrastructural, and psychological register, and these registers are enacted differently by scholars in my two cases, China and India. The paper proceeds by presenting first theory and method, analysing each of the four registers, discussing the sources of comparative differences between the two cases, and finally concluding.

\section{Theorising the Relationship Between the State of Emergence and State of Knowledge}

The relationship between power and knowledge is a key theme in post-positivist and reflexive IR which interrogates, among other things, how dominant knowledges and dominant international political practices are co-constitutive of each other, how epistemic discourses not only describe but also constitute, reproduce, and legitimate world politics, and how the knowing subject is always 
situated, its theories intrinsically normative, political and ideological and its perspective always a partial view from somewhere (for overviews, see Oren, 2018; Bueger, 2014; Allan, 2018). This paper contributes by studying the particular world-situatedness that is 'risingness' or 'emergence' and the equally particular power-knowledge link between the state of emergence and the state of knowledge. I do not claim 'risingness' is the only kind of situatedness for scholars in emerging powers, that rising powers are the only sites 'beyond the West' where new knowledge is produced nor that knowledge production is a new phenomenon in these countries. It is worth dedicating the paper to 'risingness' alone, however, because, apart from fragments in the literature, we have little knowledge about the role it plays as a driver of theoretical innovation.

Early IR inquiries into the relationship between power and knowledge also emphasised how geopolitical 'rise' can shape knowledge production. Carr (1939) stressed the difference between the status quo perspectives of (declining) Anglo-Saxon 'Haves' and the anti-status quo perspectives of (rising) 'Have-nots' like Germany, Italy, and Japan. In Hoffmann's (1977: 43) account, the political circumstance enabling the birth of IR as an American social science was "the rise of the United States to global power" and the need for intellectual underpinnings to American power projection. Robert Cox's maxim that "theory is always for someone and for some purpose" also emphasised how relative 'rise' or 'decline' conditions theories: "the world is seen from a standpoint definable in terms of nation or social class, of dominance or subordination, of rising or declining power, of a sense of immobility or of present crisis, of past experience, and of hopes and expectations for the future." (Cox, 1981: 128).

Studies of IR beyond Euro-America also contain indications that rising powers view the world differently and may become sites for theorising. Acharya and Buzan's (2010: 2, 227-228) survey of 'Non-Western IR' focused on Asia, the "only contemporary non-Western concentration of power and wealth", and concluded that "great powers often produce theories of international relations". Acharya (2011: 625) later asked "whether the development of distinctive schools of IR theories are the exclusive preserve of great powers, for example China, Japan, India and so on" and answered that this "would be hardly unusual given the historically close nexus between power (Britain, Europe and the USA) and the production of IR knowledge." (also Mallavarapu, 2012: 22; Paul, 2017: 5). Tickner and Wæver's (2009: 336) survey of IR 'beyond the West' found a dearth of theorising, except in China and emphasised its geopolitical rise as possible explanation: "a great power needs considerable paraphernalia, not least of which an independent IR school". Later volumes confirmed that "we find efforts to create local schools of IR thought only in those countries that exercise substantial or rising international influence" (Tickner and Blaney, 2012: 8). The relationship between rising power and knowledge production is sometimes phrased in causal-functionalist terms: "rising powers seem to get the IR they need" (Bajpai cited in Mattoo, 2009b). Elsewhere, it merely reflects the expectation that rising powers are the most likely sites for counter-hegemonic IR, e.g. when Keohane (2009: 40) expects that "our implicit hegemonic assumptions will continue to hamper our vision until scholars from Brazil, India and China, and other emerging great powers become more prominent in the field."

The 'theorising powers thesis' covers various, loosely conceived, power-knowledge couplings between geopolitical risingness and theoretical developments in the discipline. Sociologists and historiographers of IR have long expressed scepticism towards such explanations, arguing that causal connections between 'external' political developments in world politics and 'internal' academic developments are vague, often assumed rather than demonstrated, and create "coherence and necessity" where there is heterogeneity (Wæver, 2007: 7, 1998; Schmidt, 1998, 2018). Historiographers largely reacted by delving into the micro, historical and 'discursive-internalist' (e.g. the first debate, Schmidt, 1998, 2018; Ashworth, 2002) while sociologists of IR proposed more nuanced externalist approaches to study how not only macro-political events but sociological variables like foreign policy, political culture, policy-academia links, institutional arrangements, and 
disciplinary delineations affect internal theoretical conversations (Guzzini, 1998; Wæver, 1998; Breitenbauch and Wivel, 2004; Jørgensen and Knudsen, 2006; Grenier and Hagmann, 2016). The historiography and sociology of IR were both predicated on a critique of simplistic externalist accounts where the field of reality (international developments) determines theorising (IR). Rather than simply assuming direct links from power to knowledge, they argued, we need to study the development of ideas and theories in their academic, not only political, context, and to empirically document the causal influence of latter, if it exists at all (a strangely causal and positivist requirement considering both research programs emerged from reflexive or post-positivist IR). More problematically, internalist and externalist explanations both retain the premise that we can distinguish ontologically between science-internal and -external factors, both view the internal as the sphere where intellectual debates unfold and attribute sociality and politics mainly to the external, and disagree mainly over the relative priority given to external/social/contextual versus internal/scientific/anti-contextual explanations (Holden, 2002: 259; Wæver, 2007: 6; Breitenbauch, 2013: 25-27).

This epistemological and ontological starting point is out of sync with developments in science and technology studies (STS). STS has a longstanding interest in the relation between "most esoteric sciences and the most sordid politics" (Latour, 1993: 1). The theoretical starting point here is not to a priori distinguish between politics and science, external and internal, power and knowledge and then determine the interaction between them — or reunite them with a "mysterious slash" - but to trace the hybrid associations between them (Latour, 1999: 262; also Bueger and Gadinger, 2007: 105). STS analyses of the mutual entanglements of science and politics achieved their most developed conceptualisation in the "co-productionist" framework of Sheila Jasanoff and co-contributors in States of Knowledge (2004). The co-productionist framework rejects the dual reductionisms of science as simple reflection of truth and science as simply epiphenomenal of socio-political developments (Jasanoff, 2004: 3). Instead, Jasanoff directs attention to how scientific and political orderings "co-produce" each other; how knowledge is both a product of social work and constitutive of forms of social life. Scientific knowledge, she argues, "both embeds and is embedded in social practices, identities, norms, conventions, discourses, instruments and institutions - in short, in all the building blocks of what we term the social." (Jasanoff, 2004: 2).

By pointing to how science "embeds and is embedded in" the social, co-production stresses that science is never only a representation of the world 'as it is' but also as it should be. Scientific solutions to problems of social order are embedded in normative understandings of what are the right and relevant questions. Co-production is defined by "the proposition that the ways in which we know and represent the world (both nature and society) are inseparable from the ways in which we choose to live in it." (Jasanoff, 2004: 2, 38). This calls for an analytical symmetry that underscores both the situatedness of knowledge (scientific knowledge is produced by human beings with particular political motives and biases, situated in institutions and societies with certain norms, problems, and priorities) and that scientific knowledge co-produces social order (scientific knowledge is also involved in constituting, modifying, and legitimating state power).

I use the co-productionist idiom to study whether and how 'states of knowledge' are also inseparable from 'states of emergence'. The co-productionist move beyond internalism-externalism enables us to see that the 'state of emergence' is not an exclusively external condition causing changes in an otherwise pure internal knowledge production. The state of emergence is part of the context academics in 'rising powers' find themselves situated in, a collective sense of mobility, aspiration, and future importance that operates 'within' science as a sensibility, ethos and motivation for scholars. I examine co-productive associations between states of emergence and knowledge by studying how scholars working in 'rising powers' make sense of the emerging condition and justify their actions within it. This reflects the ethnomethodological preference in STS and pragmatic 
sociology to "follow the actors"; i.e. the task of the analyst is not to limit actors to informers and teach them what is an acceptable explanation of their actions - which would afford an unreasonable degree of interpretive power to the analyst - but to grant them back the ability to make their own theories and follow them as they make new associations (Latour, 2007: 11-12; Boltanski and Thévenot, 2006: 12; also Bueger and Gadinger, 2014: 52). The point is not to make the "short-circuit fallacy" of drawing direct, unmediated links from the broader social universe to scientific practice (Bourdieu and Wacquant, 1992: 69), but to retain the ethnomethodological sensitivity to detect how actors themselves make mediated short-circuits between the worlds of politics and science (Latour, 1999: 86-87). In this case, how scholars themselves make associations between the state of emergence and state of knowledge. By examining how scholars in emerging powers experience changes in the wider social universe, namely geopolitical risingness, and how these affect their knowledge production, we find that the state of emergence is not a uniform condition. IR scholarship in emerging powers embeds and is embedded in the 'state of emergence' in different ways (the four registers of co-production below).

\section{Method}

I therefore examine the relationship between the state of emergence and state of knowledge comparatively. A comparative design allows us to systematically compare IR in emerging powers and potential differences in how 'risingness' is experienced. I select China and India as cases for two reasons. First, in terms of the state of emergence, they are the largest, 'most emerging' of emerging powers. China and India have experienced sustained economic growth, trade and investment expansion, increasing political influence, and already rank among the five largest global economies, populations, labour forces, and military spenders (CIA, 2019; SIPRI, 2018). The state of emergence is not only an objective condition of economic-military growth or expanding foreign policy, however, but also a domestic state of aspiration and contestation over future identities in world politics (Miller, 2016). In that regard, especially China but also India are obvious candidates. Second, in terms of the state of knowledge, existing studies suggest there are debates on how to develop 'indigenous' IR theories in both China and India. Chinese scholars ask if China's rise will lead to the construction of Chinese IR theories (Qin, 2009: 195, 2011: 250, 2012: 50; Wang, 2009: 114) and debate how to construct a "Chinese school of IR" (Zhang and Chang, 2016; Kristensen and Nielsen, 2013; H.-J. Wang, 2013; Kim, 2016; Peng, 2018). Scholars have issued similar calls for India as a rising power to become an intellectual power, although the calls are more for "post-Western" than "Indian" theorising (Behera, 2007; Mattoo, 2012; Shahi, 2013; Shahi and Ascione, 2016; Vanaik, 2017).

Within Chinese and Indian IR — broadly defined, including International Studies, the preferred term in India-I select interviewees based on a purposive sampling that aims for inclusivity and diversity in order to capture the heterogeneity of the fields. I include scholars from different vertical (rank, reputation, generation) and horisontal positions (cities, institutions, schools, paradigms). Institutionally, I include both universities and think tanks but, for feasibility reasons, focus on the main IR centers in Delhi, Calcutta, Beijing, and Shanghai. Interviews were conducted, in English, with 74 researchers from 2010 to 2014 (see appendix). The risk of systematic bias, e.g. self-selection due to language capabilities, is somewhat limited as there was a $76 \%$ response rate in China and $78 \%$ in India, of which only 4 Chinese and no Indian scholars declined. Interviews were semi-structured based on two clusters of questions relating to (1) the content of IR theory debates and (2) form, working conditions, institutions, and relationship to policymaking. Research for this paper specifically coded passages on the 'rise' and 'emergence' of China and India, and how it affects the content and form of IR theorising. My focus is on IR theory, rather than knowledge production in general, given its centrality in the literature above (and that on Western dominance). Interviewees 
were promised anonymity and quotes, all from tape-recorded interviews, are identified only by country, city, institution type, and rank.

\section{The Constitutive Register: Emerging Powers, Objects, and Perspectives}

Co-production in the constitutive register concerns the constitution of epistemic objects. It refers to the "objectual practice" of rendering international phenomena knowable - by transforming them into thing-like objects - and thus governable (Cetina, 2016; Bueger, 2015; Allan, 2017). In this case, to associations between the growing global interests and systemic stakes of emerging powers and the expanding epistemic object(s) of their IR scholarship - e.g. the global economy, global trade, global climate, global order, global power transition - that require both knowledge and political action. These global epistemic objects are neither new nor the preserve of emerging powers, but the reasoning found in the interviews is that the state of emergence is conducive to universal 'big thinking' and theorising about the global order per se. Whereas smaller powers tend to focus on their own foreign policy, bilateral relations, and regional environment, rising powers with growing global interests, power, and influence will, even if they focus on their own foreign policy, inevitably have a more global epistemic object (cf. Hoffmann, 1977: 43, 48). Chinese interviewees operate in the objectual part of this register, to the point of reifying China's rise. They variously designate this object as "the whole world", "the globalised world", "international society as a whole", taking "a world vision, global vision" on the "international system and world order", "a global perspective", and "global knowledge with a global vision". ${ }^{2}$ The contention is that rising powers should develop their own perspective on this epistemic object, i.e. "perceive the international order from the perspective of the Chinese". While similar arguments are found in India- e.g. calls for "an Indian approach to various global concerns"-Indian interviewees operate in a more critical mode, critical of both India's emergence and its impact on IR scholarship. ${ }^{4}$

Chinese interviewees make strong associations between a more global orientation in foreign policy and a more systemic-global epistemic object in knowledge production; an object that must be analysed from a Chinese perspective: "Because China is becoming more preeminent today and have a lot of attraction from international society, I try to think about how China can engage with the world, how China behaves in the international system and I think we need to do this from a Chinese perspective". ${ }^{5}$ Here, the new epistemic object remains China in the world, but others go further to advocate that China's global emergence requires a "global perspective" comparable to U.S. scholars whose information about even "an unknown corner of the world...is why the Americans can now play a kind of prevailing role in the world." For China to become a global power, the assertion goes, it must think globally. This, the interviewee continues, underscores "need of new theory or theoretical framework, we need such a kind of global perspective. And China is in a position to do that...it is possible for people to obtain such a kind of global perspective if you want to do that." "The state of knowledge needs to "catch up" with the state of emergence, another scholar asserts: "if China still grows then the theory research also has to catch up with the country's development... So with your country integrating more into the world then you have to develop your own explanation about the

\footnotetext{
${ }^{2} \mathrm{C} 2 ; \mathrm{C} 13 ; \mathrm{C} 9 ; \mathrm{C} 21 ; \mathrm{C} 4$.

${ }^{3} \mathrm{C} 27$.

${ }^{4} \mathrm{I} 37$.

${ }^{5} \mathrm{C} 10$.

${ }^{6} \mathrm{C} 21$.
} 
relations". Conversely, if "you want to develop a grand theory", this scholar continues, you need to take a global-systemic perspective, "to stand on the global interest, to understand the whole world."7

Co-productive arguments in the constitutive register also take a form where rising geopolitical influence affords greater political action space, including a space to constitute, define, and provide Chinese visions for the world rather than accept the world as it is. Contrasted to the past when China was forced "to adopt all things Western", a scholar argues its rise affords the "luxury of making your own choices" which requires China to be "inspiring and innovative enough that we want to be a new power in the world, providing some new positive things in the vision of the world order." 8 The constitutive argument that the state of emergence stimulates not only system-level thinking but the formation of distinctly Chinese perspectives on the global is also present in the literature on Chinese IR. The main proponent of a Chinese School argues China's rapid development, expanding global interests, and increased "interaction with the rest of the world" has "encouraged the development and promotion of a Chinese school of IRT" (Qin, 2009: 195, also 2011: 250) because China needs to renegotiate its place in international society and "inevitably" must construct its own IR theory for that purpose (Qin, 2012: 50). The association between China's position in the world and a more global, systemic, and theoretical, orientation in IR functions as an important motivation for scholars. However, co-productive associations in the constitutive register are not unidirectional-science simply catching up with a new epistemic object 'out there'-but co-constitutive. Chinese scholars largely take China's rise for granted and debate not whether China is rising or not, but whether it is rising or has risen (Breslin, 2017; Pu and Wang, 2018). By taking its rise for granted, indeed reifying it, Chinese scholars are complicit in constituting it as an epistemic object. They are not simply observing but co-producing the state of emergence.

Comparatively, Indian interviewees are more sceptical of the 'rising India' narrative as held only by a small group of "scholars and policymakers who believe in India's destiny as a great power". ${ }^{9}$ Instead, India is variously termed a "middle power slash regional power" and "an emerging, reluctant power" that "wants to rise" and "is striving and aspiring to rise as an economic power" (cf. Destradi, 2017). One even argues India "is not emerging, it is going down the drain. See what problems we got". ${ }^{11}$ The state of emergence is thus more subdued, if not outright rejected, by Indian scholars. They are also more restrained concerning the impact of India's alleged 'rise' on the state of knowledge, the object and outlook of Indian IR scholarship. Directly comparing to China, one interviewee claims "It hasn't happened quite like that because the rise of India is not so marked as the rise of China in the global economy and in global politics." ${ }^{12}$ Some Indian scholars do note, however, that the "rise of India as an emerging power" has opened a space for India to redefine the world, not only in strategy and policy, but also by uplifting the "status of IR theorising in India." (Shahi, 2013: 56). As India's foreign policy globalises, scholars need to think on a "world basis" one interviewee contends. ${ }^{13}$ In this sense, the state of emergence does function, for some, as a call to start thinking 'big' about international society. In sum, constitutive arguments based on the expansion of foreign policy scope may function as justification for developing systemic and global IR theory, but this co-productive link is stronger in China where most scholars take the state of emergence as fact and make various constitutive arguments about how this relates to the state of knowledge, whereas Indian scholars are more sceptical both of its rise and its supposed relationship to scholarship.

\footnotetext{
${ }^{7} \mathrm{C} 2$.

${ }^{8} \mathrm{C} 3$.

${ }^{9}$ I29.

${ }^{10} \mathrm{I} 15$; I22.

${ }^{11} \mathrm{I} 20$.

12 I15.

${ }^{13} \mathrm{I} 22$.
} 


\section{The Civic Register: Emerging Powers, Problems, and Obligations}

Co-production in the civic register revolves around notions of scholarly responsibility, societal and political relevance, and policy and public engagement (Tickner, 2006; Lawson, 2008; Jahn, 2017). Compared to the object-oriented constitutive register, the civic is problem-oriented. It connects science and politics via a pragmatic commitment to "real-world problem-solving" and the vocational impulse that knowledge-making must be of interest to non-academic audiences (Abraham and Abramson, 2017). In this case, the civic register connects the states of emergence and knowledge through a problem-solving ethos: IR scholars, as citizens in emerging powers, experience growing demand, and even obligation, to provide expertise that solves the problems facing emerging powers. The reasoning is that rising powers face specific 'rising power problems', which Western IR (theory) cannot solve. This requires 'indigenous' knowledge: "to find an Indian solution to Indian problems", "to do more research on Chinese problems", and answer "a specific question with Chinese characteristics". ${ }^{14}$ The civic register contains two modes: the policy mode where the role conception is the advisor, the civic obligation is to serve the state, and the political function of scientific knowledge is to make better decisions versus the public mode where the role is the public intellectual, the civic obligation lies with civil society, and the function of knowledge is to enrich public discourse, 'speak truth to power', and contribute to issues of public concern. The two overlap with distinctions between "state counsellors" and "partisans" (Mäkinen, 2017), "gap-bridgers" who advocate for policy relevance versus "gap-minders" who argue political relevance requires distance from policymaking (Jahn, 2017: 24) and "problem-solving" intellectuals who take the world for granted, aim to make it work more smoothly, and primarily serve the state and status quo versus "critical" intellectuals who stand apart from it, ask how it came about, and challenge it (Cox, 1981). In the policy mode, prevalent in China, the state of emergence materialises in a sense among scholars that politicians in emerging powers increasingly need their advice to solve obstacles on the path to great power status: to "help our government to deal with those new challenges" and "find solutions to the serious problems". ${ }^{15}$ In India, more interviewees operate in the public mode where scholars have a civic duty to address the particular problems facing emerging societies - by critiquing, not necessarily advising, the state.

In China, there is a strong sense that the state of emergence engenders growing public demand for IR expertise. Primarily from government, but also media and students. The demand-driven logic behind the civic register is exemplified by the argument that "When you are becoming a global player there is a huge demand on how the country can cope with this growing influence and how to find solutions to the serious problems... There is huge demand, the government is looking for solutions. And also there is a huge growing demand among the public about what is going on in the outside world." "Several scholars saw their role as "to satisfy the large Chinese demand of understanding the outside world [and] help the society understand the outside world better." 17 While some view the public as their audience, the modus remains problem-solving and policy-oriented. One scholar directly applauds how the government's encourages scholars to "serve the needs of Chinese social, economic and political development", "integrate our theoretical studies more effectively with the Chinese foreign practices", and "provide the answers [to] help our government to deal with those new challenges." 18 It is a widely held perception that both media and government demand policy analysis,

\footnotetext{
${ }^{14}$ I24; C24; C10.

${ }^{15} \mathrm{C} 9 ; \mathrm{C} 3$.

${ }^{16} \mathrm{C} 3$.

${ }^{17} \mathrm{C} 1 ; \mathrm{C} 28$.

${ }^{18} \mathrm{C} 9$.
} 
area expertise, advice on pressing day-to-day issues, and, as another interviewee remarks, are "not so concerned with theory. They want answers to problems in the reality." 19 (cf. Avey and Desch, 2014: 231-232). Here it is important to emphasise that power-knowledge is not a simple demand-supply relation. Statements in the civic register are not causal-functionalist axioms that new knowledge, including theories, will automatically emerge to satisfy an already-specified demand from policymakers, but rather appeals to the obligation of scholars to supply theoretical and intellectual visions that address our problems, provide strategic and foreign policy guidance, and worldviews. Whether policymakers in rising states really need indigenous IR theories to solve their problems or not, scholars sense a "need" and "obligation" to construct one: "as China's role in the world is becoming more important and as China needs more, you know, we need more intellectual constructions to guide China's foreign policy into this world". ${ }^{20}$

Driving the obligation to build "intellectual constructions"-notably Chinese IR theory-is the rationale that rising powers cannot rely on theories addressing the problems, political needs, economic situations, and strategic environments of status quo powers. Hegemonic stability theory is highlighted as a theory that "serves America's interest" whereas "China has its own problems and the context may be different from other countries." ${ }^{21}$ How to maintain leadership and institutional dominance 'after hegemony' is another "typical American" problem, "not a Chinese problem". ${ }^{22}$ Several interviewees argue Western theories can explain American and European "foreign policy and their viewpoints" but not "China's situation, China's behaviour" and therefore "the Chinese believe it is better to develop something that can resolve those problems for the Chinese, for themselves, a kind of new theory." 23 As one interviewee asserts, "[M]any theories cannot explain what happened in the last few years in China or in the world. Especially in the context of the rise of China. In this sense you need new theory and that is the point. There is a need for it. I will say that the Chinese scholars sense this." ${ }^{24}$ How China can rise peacefully is a "question with Chinese characteristics" because "according to Western theories it is very difficult to rise peacefully", another scholar contends, which also presents an intellectual opportunity because "these kinds of questions can be helpful for us to develop a school of Chinese IR theories". ${ }^{25}$ Numerous interviewees single out "how to achieve the peaceful rise of China" as the crucial problem and theoretical "hard core" for a Chinese School (cf. Qin, 2007, 2011). "Chinese IR scholars should pay more attention to Chinese problems", one interviewee argues, specifically "how China as a great power, as a rising power, peacefully engages in the international society" and "should keep in mind that we have an obligation or duty to create a Chinese IR school." ${ }^{27}$ The civic justification for developing alternative theories about peaceful rise is not only that Western theories cannot explain the problems facing rising powers, but also to desecuritise China's rise and educate sceptical Western audiences about China's peaceful intentions. One scholar clearly explicates, "We have to build a theory to explain why China is a peaceful power when China becomes a great power... That issue needs a theory in order to understand it, to help you, Europeans and Americans to understand this issue." 28 The civic register thus has multiple audiences, not only governmental and domestic, but also civil society and international.

\footnotetext{
${ }^{19} \mathrm{C} 8$.

${ }^{20} \mathrm{C} 19$.

${ }^{21} \mathrm{C} 2$.

${ }^{22} \mathrm{C} 17$.

${ }^{23} \mathrm{C} 21 ; \mathrm{C} 10 ; \mathrm{C} 11 ; \mathrm{C} 1$.

${ }^{24} \mathrm{C} 21$.

${ }^{25} \mathrm{C} 10$.

${ }^{26} \mathrm{C} 8$; C17; $\mathrm{C} 26$.

${ }^{27} \mathrm{C} 24$.

${ }^{28} \mathrm{C} 20$.
} 
In India, civic arguments operate more in the public mode. There is a discernible sense of disconnect between academia and the state: "the Indian state doesn't need its universities", Indian IR scholars" "involvement in policy is as close to nil as possible, tending toward zero" and has "less than zero impact" and the government neither demands nor supports theorising: "They need area studies experts...not typically a theoretician" and "they think that theories don't help much". ${ }^{29}$ Although the government "hardly bothers" about IR, a few interviewees suggest this may change "as India becomes more important" and that the demand for IR expertise "will probably rise in the years to come" because "India is emerging as an economic power and India's involvement is growing more in parts of the world, so the Indian government needs more and more people." ${ }^{30}$ Many Indian interviewees do not lament the disconnect, however, because the role of scholars in the public-critical mode is not to advise policymakers on how to solve problems, but to question the very constitution of political problems, reveal modes of domination, pose problems differently, and even "problematise the entire national project" as one interviewee proclaims (cf. Zambernardi, 2016: 13; Abraham and Abramson, 2017: 31). ${ }^{31}$ In contrast to China where the Chinese School and the government's strategy find a common ground for problem-oriented theorising on China's (peaceful) rise, Indian scholars are more critical of deploying intellectual resources for the state's emerging power project. Interviewees who advocate for theorising "voices of the South" cautiously stress it should avoid becoming a "nationalist" project and that "not all of it would agree with a rising India campaign. These are critical voices, not just critical of Western IR theory but critical also of, let's say, India's strategic behaviour today. It need not always jump onto the bandwagon of an emerging power." 32 Indian interviewees are generally more critical of the state and its "rising India campaign". "Now that India is rising", one interviewee laments, there is an attempt to couple academia to the rising state to support the narrative that "we are the Indians, we are going be a big shot country in the world and all the rest. We are so wonderful...this element of nationalism is undoubtedly there". ${ }^{33}$ This critical deployment of the civic register-speaking truth to power-is rarer in China.

When Indian scholars do deploy the civic register, the commitment is to enlightening the Indian public and civil society, not the higher echelons of government (cf. Abraham and Abramson, 2017: 35). "[I]t is not that the government asks me to write all the time", a think tank scholar argues, but "I feel this obligation that I have to make the society, this nation and this world a better place." The attachment to society, how to improve it, make it secure and prosperous, he continues, "is what I mean by national obligation. It doesn't have any, you know, hard approach or nationalist approach." 34 Being nationalist, even government- and policy-oriented, is seen as more negative than in China. The problem of developing a national strategy of 'rise' therefore does not figure as prominently as the strategic problem to tackle among Indian scholars. There are, however, critiques of the inability of Western theories to explain the problems, histories, and realities of emerging societies in the South: "I do believe that not all the Western theories are well-equipped to illuminate the development in the Global South...for emerging societies like India, like China, like BRICS as you say, these are inadequate." 35 Indian interviewees also critique Western IR for having different definitions of "what is an interesting problem", arguing that emerging countries "face problems which are not on the radar screen" in Western IR, and that Indian scholars should "offer answers to problematiques that are emerging elsewhere". ${ }^{36}$ Compared to China, however, these critiques are not focused on Western IR

\footnotetext{
${ }^{29} \mathrm{I} 8 ; \mathrm{I} 4 ; \mathrm{I} 31 ; \mathrm{I} 22$

${ }^{30} \mathrm{I} 29 ; \mathrm{I} 31$.

${ }^{31} \mathrm{I} 8$.

${ }^{32} \mathrm{I} 17$.

${ }^{33} \mathrm{I} 14$; also I1; I13

${ }^{34} \mathrm{I} 21$.

${ }^{35} \mathrm{I} 31$.

${ }^{36} \mathrm{I} 8 ; \mathrm{I16}$; 115.
} 
theories' predictions about rising powers and unpeaceful power transitions but their unfitness in emerging Southern societies, and in this respect the audience differs too.

\section{Infrastructural Register: Emerging Resources, Institutions, and Disciplines}

Co-productive arguments in the infrastructural register take a more material-institutional path from state of emergence, featuring as a condition of economic growth and opening up to the world, to the state of knowledge by shaping organisational and disciplinary configurations. It refers to connections between politics and science, not knowledge, and works only indirectly via institution-building, growing research funding, and improved working conditions, which, in turn, afford greater autonomy, international connectivity, more resources and incentives for scholars to theorise (cf. institutional sociology of IR: Jørgensen and Knudsen, 2006; Grenier and Hagmann, 2016; Oren, 2016). In this register, Chinese scholars operate in an arriviste mode: China's rise created a research infrastructure that allowed IR to emerge from stages of isolation, opening up, copying, and finally culminating in theory construction. Comparatively, Indian scholars operate more in a laggard mode: a general sentiment that India's rise has not yet translated into a material-institutional IR infrastructure appropriate for a rising power.

China has experienced immense growth in scholars, institutions, journals, funding and today boasts one of the world's largest IR communities, second only to the U.S. (Qin, 2007: 316; Wang, 2009: 107). The expansion of Chinese institutions and journals has created a career infrastructure, bypassing the Anglo-American core, where Chinese theoretical discourse can flourish (Kristensen and Nielsen, 2013). The experience of economic growth and material-institutional expansion was widespread in interviews. ${ }^{37}$ "Definitely IR is booming as a field, attracts a lot of people, a lot of students", one Chinese professor remarks, "It is behaving like a growing power. You have extended your attention to every corner of the world and every aspect of international relations." 38 Although several interviewees emphasise that growth in funding is primarily directed to education while governmental research funding prioritises "policy issues" and "not theory", 39 improved material conditions increases the autonomy of the IR community to prioritise theoretical research. As "the Chinese economy grows, both the university and the Ministry of Education have much money", one scholar notes, there is more support for theoretical research because "the Chinese IR community found out that the theoretical study is very important to the development of Chinese IR study in the future... So that is why we have to put more resources into theory studies in the future." 40 The growth of funding to research and higher education ("overall investment is much larger than before") is seen to facilitate theorising through a growing division of labour and a diversification of research topics, including more theoretical and philosophical ones. ${ }^{41}$

Infrastructural growth is coupled with an arriviste, almost teleological, narrative of disciplinary emergence. The history of Chinese IR is told as series of stages culminating in the rise of China and Chinese IR theory. IR under Mao is portrayed as institutionally weak, "very closed to the outside world", not proper theoretical IR but "foreign policy study", and 'theory' was dominated by MaoistMarxist orthodoxy. ${ }^{42}$ The main infrastructural juncture, in most accounts, was Deng Xiaoping's 'Reform and Opening Up', which broke from ideological dogmatism and encouraged international

\footnotetext{
${ }^{37} \mathrm{C} 2 ; \mathrm{C} 10$.

${ }^{38} \mathrm{C} 3$.

${ }^{39} \mathrm{C} 3$; C10; C20; C22.

${ }^{40} \mathrm{C} 22$.

${ }^{41} \mathrm{C} 11$.

${ }^{42} \mathrm{C} 14$; C5.
} 
connectivity, thus allowing a 'new generation' to travel to the West (the U.S.) and return as "the first scholars to introduce Western international theories to China." 43 During this "first stage", "basic period" or "preparation stage", American IR theories like realism, liberalism and later constructivism were introduced. ${ }^{44}$ Then followed a "second stage" of applying and critiquing Western theories while debating how to construct "IR with Chinese characteristics". 45 These initial "stages" play an important role in the discourse on China's disciplinary emergence by laying a "very important foundation for further theoretical development in China" and arriving at the "same level" where "there is not a big gap between the academic community inside China and the rest of the world". ${ }^{46}$ Finally, with China's rise, Chinese IR arrives at the final "third stage" of theory construction and the "Chinese school": 47 "we have learned from the West, many things. Almost coming to some kind of final stage and then I think Chinese will become more Chinese in future." 48 The state of emergence features here as a communal sense of intellectual arrival for the Chinese IR community: "we have arrived at that stage". ${ }^{49}$ The literature on Chinese IR expounds similar sentiments (Qin, 2007, 2011; Wang, 2009).

In India, there is not a comparable arriviste-teleological narrative of disciplinary emergence. Even though International Studies has expanded institutionally and is by some estimates taught at more than 150 universities (Alagappa, 2009: 10), most interviewees express disenchantment that India's rise has not translated into its IR infrastructure; that India is lagging behind from what is expected from a rising power: "IR studies in India itself is not, is considered as not up to that mark which still requires for an emerging power" and "There should have been several more institutions, which taught and thought about these questions, for a country of this size. I think it's appalling." Interviewees lament that the IR infrastructure remains centred on Delhi, even Jawaharlal Nehru University ("tragic", "inordinately loud", "entirely negative"), and the "lack of interest in promoting institutionalised focused study of international relations across the country". ${ }^{51}$ There is no sense that India's emergence generates significantly more funding, but plenty complaints over the lack of funding for international travel, fieldwork, and, in some institutions, access to publications - the only silver lining being the freedom to "write on your own because anyway you have your salary". 52 Several interviewees also lament the qualitative state of Indian universities (not "research universities", "primarily teaching institutions", "infamous for inefficiency") and IR where you can "finger count" the people who do theoretical research ("we are operating in a sea of mediocrity"). ${ }^{53}$ International Studies, as the field is called, is critiqued for being a-theoretical, conflated with area studies, and institutionally too broad. ${ }^{54}$

Overall, there is significant disillusionment with the state of Indian IR and no comparable sense that it is entering a theory construction stage. Some do see hope for the future, however, because "India is realising that to keep itself as an emerging power or once it has emerged, it will need its own

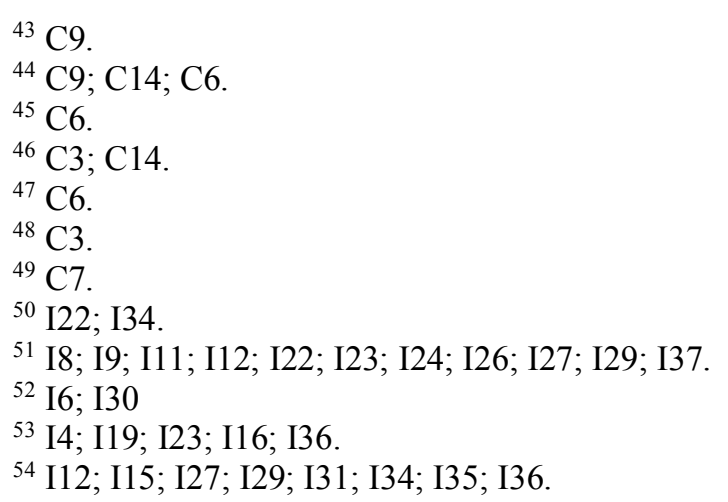


base of ideas" and the government therefore is "working hard to upgrade universities." 55 One interviewee points to the establishment of new schools, partly a reflection of India being "an emerging country and therefore perhaps greater resources, both material and human resources, are being devoted to foreign policy, international relations, IR theory" as potentially laying the foundation for Indian IR theory: "ten years from now a far larger number of institutions and scholars working on IR theory. So ten years later maybe there would be an Indian school of IR theory. Not at this stage, not now." ${ }^{56}$ Yet, even this (minority) view that India's state of emergence may eventually translate into the state of knowledge through infrastructural expansion, continues to operate in a laggard mode ("not now"). Articles on Indian IR confirm the disenchantment and belatedness (Alagappa, 2009; Mattoo, 2009a).

\section{The Psychological Register: Emerging Powers, Attention, and Confidence}

In the psychological register, the state of emergence affects the state of knowledge by enhancing the attention to, recognition, and confidence of IR scholars in emerging powers. The logic is that expectations of future power generate growing international attention to what emerging powers think. This growing attention is either motivated by the (Western) desire to understand their foreign policy and 'how rising powers think' (Callahan, 2008: 749; Geeraerts and Men, 2001: 251; Shahi and Ascione, 2016: 314; Mallavarapu, 2009: 166) or (Western) recognition of its own parochialism which creates a market for "other" voices (Tickner and Blaney, 2012: 5). Either way, the perceived effect is growing attention and recognition; a sense that the voice of emerging powers is heard and taken more seriously than that of smaller powers. This attention can both elicit a misrecognised and self-effacing stance where the lack of indigenous theory is deemed unworthy for countries of China and India's power and civilisational stature or a self-assured and confident sense that the "time has come" (Ayres, 2018) for scholars in emerging powers to show that "we can think" and "let the world hear the Chinese voice". ${ }^{57}$ In both China and India, the state of emergence generates confidence, aspirations, and expectations among scholars that their country's rising power should translate into innovative perspectives and eventually theorising, but also dissatisfaction that indigenous theories have not been produced or recognised yet. The two cases are more similar here, although Chinese interviewees operate more comfortably in a recognised and self-assured mode and Indian interviewees more towards the misrecognised and self-effacing mode with a more critical attitude towards this newfound attention.

In China, it is a widespread sentiment that Chinese IR gets more attention due to an external desire to know more about the country, its foreign policy, and how rising powers think ("they want to understand what is going on in China"). ${ }^{58}$ A scholar outlines the sentiment when arguing that China's "influence is increasing so very naturally people will pay more attention to China... So it seems you have more space to develop yourself if you work on something about China." 59 A discursive "space" is opening for scholars to speak on all things China, including Chinese IR theory. On the one hand, this boosts confidence: "the rise of China has strongly strengthened the selfconfidence of the Chinese scholars. This is a very important psychological moment." 60 The attempt to develop Chinese IR theory, another interviewee conjectures, "probably also has something to do

\footnotetext{
$55 \mathrm{I} 22$.

${ }^{56} \mathrm{I} 26$.

${ }^{57}$ I13; C9.

${ }^{58} \mathrm{C} 3$.

${ }^{59} \mathrm{C} 14$.

${ }^{60} \mathrm{C} 21$.
} 
with the strengthening or upgrading of China's international status" because it has generated a sense that its scholars, too, should "let the world hear the Chinese voice." ${ }^{61}$ On the other hand, the Western gaze renders visible the "lack" of IR theory: "if you go abroad, Western scholars will ask me as you ask me why China does not have its own theories in the area of International Relations. Do we lack the ability to build a new theory? No...A great power needs its own theories, right?" 62 In the encounter with 'the West', the lack of a recognised Chinese IR theory is deemed unworthy for a rising great power. "I went to America and also to the British I found that it is important that we say something", another scholar recounted, "we should have ourselves some ideas, we should know China, we should have the Chinese school. So that way we can stand in the world...Otherwise we have no place in the world." ${ }^{\prime 3}$ The psychological justification for developing new theories is that, as we have emerged, it is 'unbefitting' not to have our own theories.

In India, the presumption that attention to IR scholarship is a function of the (perceived) power of the country in which scholars are based is also prevalent. One interviewee bluntly states, "you engage in the market of ideas depending on how your country is perceived and how your country is perceived is how politically important a position that country makes." ${ }^{64}$ Relative rise, then, means relatively more attention, but also that emerging powers are taken more seriously and appear more persuasive. One interviewee even outlines a "power economy" theory in which you "cannot separate...IR theories and national power and economic capability". He explains that "if a country is not economically strong, it cannot really that way make its views acceptable" as was the case with India in the 1970s whereas "Now, why we are talking about an Indian version of IR. Now India is an emerging economy... because of India's economic clout, now India is being given some kind of importance...now India is taken very seriously." ${ }^{65}$ The argument is not that rising powers are suddenly producing innovative and different theories, but that they now receive long overdue attention and recognition. In the psychological register, India's emergence is in a co-productive relation to the state of knowledge because it opens a discursive space to speak and be heard ("the world is interested"). This results in growing confidence, several interviewees note, to also think theoretically about the world: "I am heard...That feeling that some people are willing to lend their ear to you, that can boost confidence", "most certainly Indians talk very confidently in seminars. They are also listened to much more. Earlier that was not the case. Western scholars for no good reason used to be condescending", and "India is seen as an emerging power, so certainly it is good news for scholars also and they feel good about it" because "it gives you a sense of confidence and it also helps you in developing a vision for the world." 66

Despite growing self-confidence, several Indian interviewees note that Indian IR remains misrecognised and entrapped in an inferiority complex. The problem, one notes, is that "we think that we don't have any IR theory, we don't have the capacity to think on the world basis... That is a psychological problem because we derived everything from the West, we talked in their terms, we talked in terms of their concepts." 67 This and several other interviewees uses the lack of independent concepts to assert that rising powers cannot simply imitate Western IR but should shed its inferiority complex. A rising India should develop its own "concepts, theories and categories", one professor notes, "to build up your own understanding of things and not be lackey of some other forms of

\footnotetext{
${ }^{61} \mathrm{C} 9$.

${ }^{62} \mathrm{C} 20$.

${ }^{63}$ C6.

$64 \mathrm{I} 26$.

$65 \mathrm{I} 31$.

${ }^{66}$ I37; I19; I21.

67 I22.
} 
thinking. Yes, for a rising power thinking on these lines in a sense is a must...There is no need to be unduly imitative." ${ }^{68}$ It is unworthy for rising powers to "allow others to label you", another argues, they have to demonstrate that they can think: "We just want to say that we can think." India must do so, she continues, to become recognised and acknowledged: "India is emerging as a major power, so India needs to manufacture now, it cannot just borrow Western theories...If you are powerful, you have to build knowledge. And if you are building knowledge that has to be acknowledged, then only you are recognised as a power." 69

The main difference from China is that some Indian interviewees take a more critical stance towards this growing attention and confidence. Even interviewees who are critical of the 'rising power' narrative agree that outsiders view India as rising and pay more attention: "people say 'oh, your country has been doing well and it's rising'. 'OK, you think so?' [laughing]...It's how others look at you more than how you look at yourself sometimes." However, this newfound attention space has certain discursive limits because the state of emergence creates a situation where only questions about India's rise, foreign policy, power transitions, BRICs, and rising powers-what the same scholar calls a low hanging "fruit"-are "hurled at you" as "they" call upon you to speak even though this is not necessarily your field of expertise. ${ }^{70}$ Others note that Western IR still sets the agenda in this recently opened space; that invitations to international projects on "Asian rising powers" are "somebody else's debate" and "somebody else's agenda" in which you are interpellated as "an Indian IR scholar" expected to speak about and "for India" which "is an absurd sort of approach" that puts you in an "inferior position". 71

\section{Comparative Discussion}

Table 1. Four co-productive registers and their modes in China and India

\begin{tabular}{lll}
\hline Registers & China & India \\
\hline Constitutive & Objectual mode & Critical mode \\
Civic & Policy mode & Public mode \\
Infrastructural & Arriviste mode & Laggard mode \\
Psychological & Self-assured mode & Self-effacing mode \\
\hline
\end{tabular}

As table 1 summarises, the constitutive register draws associations between a more global orientation in foreign policy and a more global, systemic, and theoretical orientation in knowledge production. Chinese interviewees operate in the objectual mode which takes China's emergence for granted and make strong calls for taking the world, globe, and international order as epistemic objects while Indian scholars are more critical of their role in constituting India's emergence, inclined to view 'India rising' as elitist discourse, and sceptical about its impact on the state of knowledge. In the civic

\footnotetext{
68 I19.

$69 \mathrm{I} 13$.

${ }^{70} \mathrm{I} 34$.

${ }^{71} \mathrm{I} 35 ; \mathrm{I} 27$.
} 
register, Chinese interviewees express a strong sense that the state of emergence leads to growing demand for IR expertise and conceive the civic ethos in the policy mode as an obligation to help and advise the government solve Chinese problems, i.e. problems on its (peaceful) rise to greatpowerhood. Civic arguments are not weaker but take different forms in India where scholars are inclined to operate more in a public mode where their civic duty is to address the particular problems facing emerging societies by critiquing, not supporting and advising, the state. The contrast between Chinese and Indian states of emergence/knowledge is also discernable in the infrastructural register. There is near-consensus in China that IR has undergone an almost teleological maturation process, materially, institutionally, and intellectually, and now arrived at the theory construction stage, whereas the prevailing sense in India is that its IR infrastructure lags behind and does not live up to the expectations for an emerging power. In the psychological register, there is a strong sense in both China and India that expectations for their future power results in growing attention from the outside to what rising powers think and growing confidence among scholars that they should offer something different. Yet, China is further towards the self-assured and Indian more towards the self-effacing end of this register.

Overall, Chinese IR embeds and is embedded in the state of emergence to a larger extent than Indian IR. Most Chinese scholars interviewed take the state of emergence as fact and make conjectures about how this affects the state of knowledge, whereas Indian scholars are sceptical about the state of emergence in the first place. One possible explanation is that China's state of emergence is objectively 'more advanced'. Its economy, trade, and military expenditures are around four times India's, its foreign investment almost 9 times, and its official development assistance almost 25 times (AIDData, 2018; CIA, 2019; SIPRI, 2018; WTO, 2018). China has a larger global economic, political and military presence, which partly explains why Chinese scholars, in the constitutive register, are more concerned with 'risingness' and the global context. China's expenditure in social science and humanities is around 4 times, and its personnel around 25 times, India's (UNESCO, 2016: 305-316), which partly explains differences in the infrastructural register. However, these explanations implicitly suggest that China is simply temporally 'ahead'. This has some truth to it, but I also argue that their states of emergence, and their relation to the state of knowledge, are different in kind, not simply degree.

One main difference is that China's emergence is securitised (China threat). This partly explains the desecuritising focus in the state of knowledge. The particular problem of peaceful rise in the civic register is a result of 'China threat' theories that posit China as the primary 'non-Western' challenger to American-Western hegemony. The civic duty of IR is therefore to counter pessimistic 'Western' theories about unpeaceful rise and tell 'the West' what China really wants. China's state of emergence thus provides part of the explanation why Chinese scholars search for a (Sino-centric) national approach to IR theory, a Chinese School to explain China's peaceful rise. India's emergence is not securitised and theoretical efforts are therefore not framed around the need to counter Western 'threat theories'. The political urgency to create a distinctly 'Indian IR' is weaker than during its non-aligned period or before its nuclear recognition (Mallavarapu, 2009: 169-171; Shahi, 2013: 51). Moreover, because Indian scholars are more sceptical of the rising India narrative and see a disconnect between academia and the state. India's 'rise', the problem of developing a grand strategy for (peacefully) rising is seen as the state's challenge, not a prominent academic problem.

Their states of emergence also differ as to the role of 'the West', imperialism, humiliation, and nationalism. China and India share a collective trauma as world-historical civilisations humiliated by Western imperialism, which shapes their contemporary sense of entitlement. As the psychological register illustrated, it is a widespread sentiment in both countries that it is unworthy of a rising power with a long civilisational history and philosophical tradition not to have its own IR theory. But their colonial experiences were also different-India was colonised by the British for 200 years, China 
was subject to piecemeal colonial rule by Western and Japanese empires (Miller, 2013). Coloniality also shapes the state of knowledge differently, in China's case in a more nativist and in India's a more postcolonial orientation. Many Chinese interviewees aim their critiques of Western IR theories at their pessimistic predictions concerning China's rise, veiled attempts to prevent China's rightful rise, and support the development of a Chinese theory for China, drawing on Chinese philosophy, culture, and historical experience. Chinese scholars write primarily for a national and policy-centric audience and secondarily for 'the West to get China right'. Indian critiques are not focused so much on Western theories' predictions about India's rise, or rising powers generally, but on their unfitness to the Global South. Indian interviewees who advocate for 'theorising from India' (rather than 'Indian theorising') warn that such an endeavour should not apply only to India and solve only its problems - effectively allying with the Indian state and its rising project - but take the global South and postcolonial world as its audience. They critique the project of constructing a national theory, a distinctly non-Western 'Indian school', as too nativist considering the plurality of India's past, including its colonial past. The influence of postcolonial thought also makes many Indian interviewees more reflexive about the colonial experience, their relation to 'the West', and the possibility of recovering an innocently indigenous past. As one argues, "the West is within us". ${ }^{72}$ Colonialism does not play a prominent role in the Chinese interviews. China's past is seen as accessible, untainted by colonialism, and inherently Chinese. Sinocentrism and Chinese exceptionalism stands largely unquestioned (Zhang, 2013; Peng, 2018)

Other reasons why co-productive relations take different forms have to do with differences, not in their states of emergence, but in regime type, academic freedom, political and academic culture, and organisational context (cf. Breitenbauch and Wivel, 2004; Jørgensen and Knudsen, 2006). The Chinese political system is authoritarian and hierarchical. Its political and academic culture generally downplays disagreement and valorises harmony and loyalty. Whether or not China's authoritarian political system actually needs policy-relevant knowledge from academics, it certainly does not encourage the dissent associated with the public-critical mode many Indian scholars operate in. Selfcensorship contributes to this. In terms of academic culture, the Chinese concept of theory, in line with Marxist-Maoist tradition, is arguably more pragmatic, policy- and action-oriented (Geeraerts and Men, 2001). Meanwhile, India's democratic political system and culture valorises polyphony, pluralistic debate, and even cacophony among rival perspectives (Sen, 2006). Whether democracy and free social science research is a necessary condition for producing independent theories, except ideological ones, remains unclear, but it certainly seems a requirement for gaining global recognition as one (Buzan, 2018: 20-21). My focus in this paper has been on the relationship between the state of emergence and the state of knowledge, but the influence of 'risingness' fades once we zoom in on the specific domestic political, institutional, intellectual, and disciplinary setup. The two cases exhibit significant diversity here and further comparative research is needed to fully understand the potential shape of IR theories coming out of China and India.

\section{Conclusion}

This paper examined the relationship between the socio-political condition of 'risingness' (the state of emergence) and attempts to theorise (the state of knowledge) — a relation alluded to but rarely studied in the sociology of IR. Rather than analysing the political condition of risingness as a causal and 'external' factor that affects (or not) the otherwise pure and 'internal' dynamics of science, the paper demonstrated that the state of emergence manifests itself 'inside' science as a sensibility scholars use to make sense of their own situatedness. The associations scholars make between

\footnotetext{
${ }^{72} \mathrm{I} 8$.
} 
knowledge and power, science and politics, risingness and theorising are neither internal nor external, neither purely scientific nor purely political, but co-productive. The paper identified four registers through which such co-productive associations between risingness and theorising are made. The associations made in the four registers in various ways show how the very assumption that rising powers will become theorising powers may turn it into a self-fulfilling prophecy. The 'theorising powers thesis' works through its reflexive effects.

It works in the co-productive register because academics, particularly in China, subscribe to the idea that a more global orientation in foreign policy is conducive to more systemic and theoretical epistemic orientations in IR. In the civic register, regardless of whether the policymakers or civil societies of emerging powers really need indigenous systemic IR theories, the civic sensibility that scholars are obliged to construct new IR theories can itself function as an impetus for theorising. In the infrastructural register, the sense of material, institutional, and disciplinary arrival can itself provide momentum for the Chinese School project while excessive pessimism concerning the state of Indian IR has the opposite effect. Finally, arguments in the psychological register provide a clear illustration that the state of emergence affects theorising not only as an objective, external, and material condition but as an intersubjective sense of future importance. Here theorising efforts are justified both by the aspirations among scholars that their country's rising power should translate into innovative perspectives - a sense that 'our time has come' to show that 'we can think' theoreticallybut also by way of misrecognition and an inferiority complex vis-à-vis 'the West'. This sensibility itself provides an explanation why there are on-going efforts to construct IR theories in rising powers. It works because academics subscribe to the idea that rising powers should become theorising powers.

The four registers also illustrate that the state of emergence far from determines the state of knowledge. By engaging scholars in conversations, we realise the state of emergence affects scholars quite differently. An externalist account drawing direct, unmediated links from risingness to theorising is ultimately misleading because two of the objectively 'most rising' powers differ significantly regarding the shape and strength of co-productive associations-particularly in the constitutive, civic, and infrastructural registers. These differences are only partly explained by the 'more advanced' emergence of China, but are also products of their differing degrees of securitization, relationships to Western imperialism and indigenousness, academic cultures, sociopolitical structures, and relationships to the state project. My comparative design inevitably stressed these differences between China and India, but it is important to stress that there are also similarities among the two and differences within each. Moreover, there are 'interaction effects' in that Indian disappointment with the state of IR is often benchmarked against China and arguments against a singular 'national school' often made in contrast to an authoritarian-nationalist China and its Chinese school project. The comparative dimension is important, however, because the kinds of theory potentially coming out of China and India are likely to differ depending on the degree to which they are connected to the state of emergence and how specifically they are translated through the four registers. Whether the result of these efforts will be recognised as 'IR theory' by the 'global' discipline is a question for further research.

\section{Bibliography}

Abraham KJ and Abramson Y (2017) A pragmatist vocation for International Relations. European Journal of International Relations 23(1): 26-48.

Acharya A (2011) Dialogue and Discovery. Millennium 39(3): 619-637.

Acharya A (2014) Global International Relations (IR) and Regional Worlds. International Studies Quarterly 58(4): 647-659.

Acharya A (2016) Advancing Global IR. International Studies Review 18(1): 4-15.

Acharya A and Buzan B (2010) Non-Western International Relations Theory. Abingdon: Routledge.

Agathangelou A and Ling LHM (2004) The House of IR. International Studies Review 6(4): 21-49. 
AIDData (2018) Datasets. Available at: https://www.aiddata.org/datasets (Accessed 29 October 2018).

Alagappa M (2009) Strengthening International Studies in India. International Studies 46(1-2): 7-35.

Alejandro A (2018) Western Dominance in International Relations? London: Routledge.

Allan BB (2017) Producing the Climate. International Organization 71(1): 131-162.

Allan BB (2018) From Subjects to Objects. European Journal of International Relations 24(4): 841-864.

Ashworth LM (2002) Did the Realist-Idealist Great Debate Really Happen? International Relations 16(1): 33-51.

Avey P and Desch M (2014) What Do Policymakers Want From Us? International Studies Quarterly 58(2): $227-246$.

Aydinli E and Biltekin G (2018) Widening the World of International Relations. London: Routledge.

Ayres A (2018) Our Time Has Come. Oxford: Oxford University Press.

Behera NC (2007) Re-imagining IR in India. International Relations of the Asia-Pacific 7(3): 341-368.

Boltanski L and Thévenot L (2006) On Justification. Princeton: Princeton University Press.

Bourdieu P and Wacquant L (1992) An Invitation to Reflexive Sociology. Chicago: University of Chicago Press.

Breitenbauch НØ (2013) The International Relations Discipline in France. London: Routledge.

Breitenbauch HØ and Wivel A (2004) Understanding National IR Disciplines Outside the United States. Journal of

International Relations and Development 7(4): 414-443.

Breslin S (2017) Still Rising or Risen (or Both)? Pacific Review 30(6): 870-884.

Bueger C (2014) From Expert Communities to Epistemic Arrangements. In: Mayer M, Carpes M, and Knoblich R (eds)

The Global Politics of Science and Technology, Vol. 1. Berlin: Springer, pp. 39-54.

Bueger C (2015) Making Things Known. International Political Sociology 9(1): 1-18.

Bueger C and Gadinger F (2007) Reassembling and Dissecting. International Studies Perspectives 8(1): 90-110.

Bueger C and Gadinger F (2014) International Practice Theory. Wiesbaden: Springer.

Buzan B (2018) How and How Not to Develop IR Theory. Chinese Journal of International Politics 11(4): $391-414$.

Callahan WA (2008) Chinese Visions of World Order. International Studies Review 10(4): 749-761.

Carr EH (1939) The Twenty Years' Crisis, 1919-1939. New York: HarperPerennial.

Cetina KK (2016) Objectual practice. In: Mazzotti M (ed) Knowledge as Social Order. London: Routledge, pp. 97-112.

CIA (2019) World Factbook. Available at: https://www.cia.gov/library/publications/the-world-

factbook/rankorder/rankorderguide.html (Accessed 9 January 2019).

Cox R (1981) Social Forces, States and World Orders. Millennium 10(2): 126-155.

Deciancio M (2016) International Relations from the South. International Studies Review 18(1): 106-119.

Destradi S (2017) Reluctance in international politics. European Journal of International Relations 23(2): $315-340$.

Geeraerts G and Men J (2001) International Relations Theory in China. Global Society 15(3): 251-276.

Grenier F and Hagmann J (2016) Sites of Knowledge (Re-)Production. International Studies Review 18(2): 333 -365.

Guzzini S (1998) Realism in International Relations and International Political Economy. London: Routledge.

Hobson JM (2012) The Eurocentric Conception of World Politics. Cambridge: Cambridge University Press.

Hoffmann S (1977) An American Social Science. Daedalus 106(3): 41-60.

Holden G (2002) Who Contextualizes the Contextualizers? Review of International Studies 28(2): 253-270.

Inayatullah N and Blaney D (2004) International Relations and the Problem of Difference. London: Routledge.

Jahn B (2017) Theorizing the Political Relevance of International Relations Theory. International Studies Quarterly

61(1): 64-77.

Jasanoff S (ed.) (2004) States of Knowledge. London: Routledge.

Jørgensen KE and Knudsen TB (2006) International Relations in Europe. Abingdon: Routledge.

Keohane R (2009) The Old IPE and the New. Review of International Political Economy 16(1): 34-46.

Kim HJ (2016) Will IR Theory with Chinese Characteristics be a Powerful Alternative? Chinese Journal of

International Politics 9(1): 59-79.

Kristensen PM (2015) Revisiting the 'American Social Science'. International Studies Perspectives 16(3): $246-269$.

Kristensen PM and Nielsen RT (2013) Constructing a Chinese International Relations Theory. International Political

Sociology 7(1): 19-40.

Latour B (1993) We Have Never Been Modern. Cambridge: Harvard University Press.

Latour B (1999) Pandora's Hope. Cambridge: Harvard University Press.

Latour B (2007) Reassembling the Social. Oxford: Oxford University Press.

Lawson G (2008) For a Public International Relations. International Political Sociology 2(1): 17-37.

Long D and Schmidt BC (2005) Imperialism and Internationalism in the Discipline of International Relations. Albany: SUNY Press.

Mäkinen S (2017) Professional Geopolitics as an Ideal. International Studies Perspectives 18(3): $288-303$.

Maliniak D, Peterson S, Powers R, and Tierney MJ (2018) Is International Relations a Global Discipline? Security

Studies 27(3): 448-484.

Mallavarapu S (2009) Development of International Relations Theory in India. International Studies 46(1-2): 165-183.

Mallavarapu S (2012) Indian Thinking in International Relations. In: Chimni BS and Mallavarapu S (eds) International 
Relations. Delhi: Pearson, pp. 22-38.

Mattoo A (2009a) The State of International Studies in India. International Studies 46(1-2): 37-48.

Mattoo A (2009b) Upgrading the Study of International Relations. The Hindu, 21 April.

Mattoo A (2012) An Indian grammar for International Studies. The Hindu, 11 December.

Miller MC (2013) Wronged by Empire. Stanford: Stanford University Press.

Miller MC (2016) The Role of Beliefs in Identifying Rising Powers. Chinese Journal of International Politics 9(2):

$211-238$

Nayak M and Selbin E (2010) Decentering International Relations. London: Zed.

Oren I (2016) A Sociological Analysis of the Decline of American IR Theory. International Studies Review 18(4): 571596.

Oren I (2018) International Relations Ideas as Reflections and Weapons of US Foreign Policy. In: Gofas A, HamatiAtaya I and Onuf N (eds) SAGE Handbook of the History, Philosophy, and Sociology of International Relations.

London: SAGE, pp. 399-413.

Paul TV (2017) Indian International Relations Studies. ORF Issue Brief 219.

Peng L (2018) Chinese IR Sino-centrism Tradition and its Influence on the Chinese School Movement. Pacific Review. OnlineFirst DOI: 10.1080/09512748.2018.1461681.

$\mathrm{Pu} X$ and Wang C (2018) Rethinking China's rise. International Affairs 94(5): 1019-1035.

Qin Y (2007) Why is there no Chinese international relations theory? International Relations of the Asia-Pacific 7(3):

313-340.

Qin Y (2009) Development of International Relations Theory in China. International Studies 46(1-2): 185-201.

Qin Y (2011) Development of International Relations Theory in China. International Relations of the Asia-Pacific 11(2): 231-257.

Qin Y (2012) The Possibility and Inevitability of a Chinese School of International Relations Theory. In: Callahan WA and Barabantseva E (eds) China Orders the World. Baltimore: Johns Hopkins University Press, pp. 37-53.

Schmidt BC (1998) The Political Discourse of Anarchy. Albany: SUNY Press.

Schmidt BC (2018) Internalism Versus Externalism in the Disciplinary History of International Relations. In: Schmidt $\mathrm{B}$ and Guilhot N (eds) Historiographical Investigations in International Relations. Cham: Palgrave, pp. 127-148.

Sen A (2006) The Argumentative Indian. New York: Picador.

Shahi D (2013) Indian Scholarship on International Relations and Multilateralism. Economic and Political Weekly 48(5): $50-58$.

Shahi D and Ascione G (2016) Rethinking the Absence of Post-Western International Relations Theory in India. European Journal of International Relations 22(2): 313-334.

Shilliam R (2010) International Relations and Non-Western Thought. London: Routledge.

SIPRI (2018) Trends in World Military Expenditure, 2017. Stockholm: SIPRI.

Smith S (2000) The Discipline of International Relations. British Journal of Politics and International Relations 2(3): 374-402.

Smith S (2002) The United States and the Discipline of International Relations. International Studies Review 4(2): $67-$ 86.

Smith S (2004) Singing Our World into Existence. International Studies Quarterly 48(3): 499-515.

Tickner AJ (2006) On The Frontlines or Sidelines of Knowledge and Power? International Studies Review 8(3): 383395.

Tickner AB (2013) Core, Periphery and (neo)imperialist International Relations. European Journal of International Relations 19(3): 627-646.

Tickner AB and Blaney D (eds) (2012) Thinking the International Differently. London: Routledge.

Tickner AB and Wæver O (2009) International Relations Scholarship Around the World. London: Routledge.

Turton H (2015) International Relations and American Dominance. London: Routledge

Turton H and Freire L (2016) Peripheral Possibilities. Journal of International Relations and Development 19(4): 535557

UNESCO (2016) World Social Science Report. Paris: UNESCO.

Van der Pijl K (2014) The Discipline of Western Supremacy, Vol. 3. London: PlutoPress.

Vitalis R (2015) White World Order, Black Power Politics. Ithaca: Cornell University Press.

Wæver O (1998) The Sociology of a Not So International Discipline. International Organization 52(4): 687-727.

Wæver O (2007) The Social and Intellectual Structure of the IR Discipline. Paper at 48th ISA Convention.

Wang H-J (2013) The Rise of China and Chinese International Relations Scholarship. Lanham: Lexington Books.

Wang Y (2009) China. In: Tickner A and Wæver O (eds) International Relations Scholarship Around the World.

London: Routledge, pp. 120-133.

Wemheuer-Vogelaar W, Bell NJ, Morales MN and Tierney MJ (2016) The IR of the Beholder. International Studies Review 18(1): 16-32. 
WTO (2018) Trade Statistics. Available at: http://stat.wto.org (Accessed 23 October 2018).

Zambernardi L (2016) Politics is Too Important to Be Left to Political Scientists. European Journal of International Relations 22(1): 3-23.

Zhang F (2013) The rise of Chinese Exceptionalism in International Relations. European Journal of International Relations 19(2): 305-328.

Zhang Y and Chang T-C (2016) Constructing a Chinese School(s) of International Relations. London: Routledge. 